\title{
PATIENT EMPOWERMENT INDEX OF DIABETES MELLITUS PATIENTS
}

\author{
Agus Heru Darjono ${ }^{1^{*}}$, Ujang Sumarwan ${ }^{1}$, Lilik Noor Yuliati ${ }^{1}$, Hari Wijayanto ${ }^{1}$ \\ ${ }^{1}$ School of Business, IPB University, Jl Raya Pajajaran, Bogor, West Java 16128 \\ "Email: agus.darjono@gmail.com
}

\begin{abstract}
The measurement of patient empowerment is important in the health care of chronic diseases, especially diabetes mellitus. The purpose of the study was to develop the patient empowerment index ('IKP'/Indeks Keberdayaan Pasien) and its dimensions (patient knowledge, patient control, and patient participation) in patients with diabetes mellitus. The research utilized factor analysis in developing patient empowerment index for data analysis. Purposive sampling has been conducted with 330 respondents of diabetes mellitus patients from 26 hospitals in Jabotabek (Jakarta, Bogor, Tangerang, and Bekasi). The variables measured using the Likert scale with a scale of 1 to 5 , in which 1 indicates the level of strongly disagree and 5 indicates the level of strongly agree. The collected data were analysed with factor analysis. The results showed that the patient empowerment index consisted of 25.84 percent of knowledge dimensions, 33.44 percent of control dimensions and 40.76 percent of participation dimensions. The total score of patient empowerment index value is 68.84 that is in the critical category, which means that consumers have control for the management of their disease conditions in their daily lives. The managerial implication based on the result was the emerging issues of the government to develop an empowerment index for each province in Indonesia that can be used as a benchmark and key performance indicator $(\mathrm{KPI})$ to measure the governance of health programs so the patient empowerment can be increased.
\end{abstract}

Keywords: chronic diseases, diabetes mellitus, empowerment, index, patient

\section{Indeks Keberdayaan Pasien Studi Kasus Pasien Diabetes Melitus}

\begin{abstract}
Abstrak
Pengukuran keberdayaan pasien menjadi penting dalam perawatan kesehatan penyakit kronis terutama diabetes melitus. Tujuan penelitian ini adalah merancang Indeks Keberdayaan Pasien (IKP) dan dimensinya (pengetahuan, control, dan partisipasi) pada pasien diabetes melitus. Metode analisis data menggunakan analisis faktor dalam merancang IKP. Responden yang terlibat dalam penelitian ini sebanyak 330 pasien penderita diabetes melitus dari 26 rumah sakit di Jabotabek (Jakarta, Bogor, Tangerang, Bekasi) yang ditetapkan secara purposive. Variabel diukur menggunakan skala Likert dengan skala 1 hingga 5 , di mana 1 menunjukkan tingkat sangat tidak setuju dan 5 menunjukkan tingkat sangat setuju. Data yang terkumpul dianalisis dengan analisis faktor. Hasil penelitian menunjukan IKP terdiri dari dimensi pengetahuan sebesar 25,84 persen, dimensi kontrol 33,44 persen dan dimensi partisipasi 40,76 persen. Nilai IKP pada skor total adalah 68,84 dalam kategori kritis yaitu konsumen memiliki kontrol atas pengelolaan kondisi penyakit mereka dalam kehidupan sehari-hari. Implikasi manajerial yang dapat disimpulkan dari hasil yang diperoleh yaitu pemerintah dapat merancang indeks keberdayaan untuk setiap provinsi di Indonesia yang digunakan sebagai benchmark dan Key Performance Indicator (KPI) untuk mengukur keberhasilan program-program bidang kesehatan terutama untuk peningkatan keberdayaan pasien.
\end{abstract}

Kata kunci: diabetes melitus, indeks, keberdayaan, pasien, penyakit kronis

\section{INTRODUCTION}

One of the Indonesian government efforts in health development during 2015-2019 was the Healthy Indonesia Program which aims to improve the community's health and nutritional status through health and community empowerment efforts that promoted by financial protection and health service distribution (KEMENKES, 2015). One of the efforts is empowerment as Ouschan, Sweeney, dan Johnson (2006) stated that the empowerment of people with chronic diseases is needed as an attempt to reduce health costs and maintain the health of patients. The focus of chronic disease in specific studies is diabetes mellitus (DM), it is a chronic disease that characterized by exceeding blood glucose levels from the normal limit and impaired metabolism of carbohydrates, fats, and 
proteins that cause sufferers to use drugs or insulin for life. Besides, DM is one of the highest non-communicable diseases that cause death in Indonesia. Based on (World Health Organization, 2012), DM is the biggest cause of death and proves an increasing pattern of DM patients in Indonesia. Diabetes has a large share of health sector expenditures because the use of drugs in diabetes is longterm and has a small tendency to shift product brands (Prabowo, Wirjodirdjo, \& Vanany, 2012). This causes less than 1.0 percent of people living with diabetes to achieve adequate treatment targets (IDF, 2017).

Patient empowerment is increasingly important for patient health care. When there is a move in Western culture towards the increase of consumerism and individualism, the institutional culture of health care is eventually moving away from the ethics of paternalism to the ethics of empowering patients in making decisions (Barr et al., 2015). Thus, the consumer behavior perspective becomes important since this is demonstrated by the desire to develop and implement a fairer and more collaborative approach on health including joint decision making (Gallan, Jarvis, Brown, \& Bitner, 2013). Empowerment described as value-oriented to work in society and theoretical models to understand the processes and the consequences of efforts in controlling and influencing decisions that affect a person's life, organizational functions, and the community's quality of life (Zimmerman, 1990). Empowerment is a method to achieve power with a process of capacity building which aims to bring a shift in social and political that supports individuals, groups, and communities who seek more control. Practitioners can engage with concerned individuals, citizens and community-based groups to help in achieving power to address micro-level community health problems. Empowerment on the analysis at individual level could be called as psychological empowerment (Zimmerman, 1990). Psychological empowerment accomodates beliefs about one's competence, efforts in exercising control, as well as awareness of the socio-political environment.

A study conducted by the Tol, Shojaeezadeh, Sharifirad, Alhani and Tehrani (2012) indicated that empowerment is a psychosocial selfefficacy. World health professionals and researchers have identified 'self-empowerment' as a key element in managing chronic diseases. In the case of diabetic patients, empowerment implies an approach attempt to improve the patients' ability to actively comprehend and affect their own lives and health status. Patients with diabetes could be empowered to manage chronic disease if adequate information and education were provided for them. A similar study was conducted by Anderson and Funnell (2010) explained about the concept of empowerment and to fix a common misconception about its practice in diabetes care and education. The results of patient empowerment research make a paradigm shift in the traditional approach to the care, training, and outreach of health care professionals (HCP). Aujoulat, d'Hoore and Deccache (2007) attempted to examine the concept of empowerment used in the treatment of chronic patients and the results showed that: (i) the purpose of the empowerment approach has not been disease-specific, more towards strengthening or developing general psychosocial skills; (ii) empowerment methods are still patient-centered and based on experience; and (iii) the relationship between health providers and patients needs to be continuously involved.

Nygårdh, Malm, Wikby and Ahlström (2012) explored the dimension of empowerment in patients with chronic kidney disease. Five out of the seven sub-themes emerged from the analysis pointed that empowerment including accessibility by following needs, confirmation of meetings, trust on the competence of the health staff, decision making participation, and self-management learning. Aujoulat, Marcolongo, Bonadiman and Deccache (2008) also explored inductive empowerment by constructing self-efficacy, mastery, and control. The findings showed that patient empowerment is a process of personal transformation that develops through a dual process; (i) 'holding' to previous selfrepresentation and the role of learning to control disease and treatment, thus to distinguish oneself from disease on the one hand, (ii) 'let go' by accepting to give up control. The process of separating identity (holding') is related to attempts to take control and maintain or regain a sense of mastery, the process to identity reconciliation ('releasing') is found to be connected with the requirement for coherence including the search for meaning and acceptance which not all controlled. The process of letting go of control is as central to empowerment as the process of gaining control. As a process of empowerment take place when patients reach the terms of their safety being threatened and identity, not only with their treatment, maybe also facilitated by the health care providers. 
Anderson and Funnell (2010) stated that empowerment aims to make an increase in the capacity of patients to think critically and become autonomous in decision making. Furthermore, empowerment occurs when patients exceptionally make autonomous decisions regarding their self-management of diabetes. Different from the traditional approach, empowerment is not something one performs for the patients. Conversely, empowerment will begin when health professionals recognize that patients are controlling their daily care. The research of the empowerment on abroad consumers has been studied quite a lot by previous researchers including Alshibly and Chiong (2015); Anderson and Huang (2006); Boyd, McGarry and Clarke (2016); Camacho, De Jong and Stremersch (2014); Cannoy (2009); Chou, Yang and Jhan (2015); Ellinger, Keller and Bas (2010); Fernandez and Moldogaziev (2013); Fong and Snape (2015); Fuchs and Schreier (2011); Khong, Onyemeh and Chong (2013); Stewart Loane and D'Alessandro (2014); and Midha (2012).

The empowerment study conducted by Almunawar, Anshari and Younis (2015) stated that there are three dimensions, namely personal, social, and medical dimensions in empowerment. In line with previous researchers by stating empowerment is related to consumer knowledge (Broniarczyk \& Griffin, 2014), culture (Camacho et al., 2014), perception (Chou et al., 2015), experience and organizational support (Hau-siu Chow, Wingchun Lo, Sha, \& Hong, 2006). There are only several similar studies related to consumer empowerment in Indonesia, some of them has been done by Simanjuntak et al. $(2013,2014)$, Simanjuntak (2014), Simanjuntak (2015), and the other one on Tuberculosis patients in Depok city by Nursasi (2015). In the previous studies, they were still focused on consumers in general. Thus, this study sought to design a Patient Empowerment Index that has not been studied by previous researchers.Chronic diseases such as diabetes mellitus require very high self-management and collaboration between patients and doctors is intensive collaboration (Ouschan et al., 2006). Empowerment of patients in their care will improve health quality and is important for the sustainability of existing health systems (Barr et al., 2015; Cannoy, 2009; Ouschan et al., 2006; Shankar, Cherrier, \& Canniford, 2006; World Health Organization, 2012). Moreover, some previous studies showed that patient empowerment has a significant impact on the quality of their treatment and also makes a big difference in terms of health costs (Barr et al., 2015; World Health Organization, 2012). The results of previous studies also revealed that patient empowerment generates an increase in patient awareness, reduces dependence on health services, adherence to treatment and measurable improvements in patient health outcomes (Barr et al., 2015; Shankar et al., 2006; World Health Organization, 2012). This study focuses on developing empowerment index and its dimensions (patient knowledge, patient control, and patient participation) in chronic disease patients. Furthermore, this study has a renewed study in specific depth empowerment on chronic patients under diabetes mellitus cases. The renewal and importance of the research are in the form of an index of the medical consumers' empowerment in chronic diseases in Indonesia.

\section{METHODS}

This research employed a quantitative research design with explanatory descriptive output. Research locations were in private and public hospitals. There were 25 hospitals spread across 8 cities and regencies, namely Bogor City, Bogor Regency, West Jakarta, Central Jakarta, South Jakarta, East Jakarta, North Jakarta, and Bekasi Regency. The hospitals were grouped into several different hospital (class) characteristics that were Class A Hospitals (6), Class B Hospitals (9), Class C Hospitals (8), and Class D Hospitals (2). Class A hospitals were chosen entirely from the list (data) of hospitals in the Jakarta, Bogor and Bekasi regions. The selection of samples in classes $B, C$, and $D$ was selected by taking into account the distribution of the location of the hospital. Besides hospital class, another characteristic also considered in choosing respondents such as the origin of the hospitalbased on ownership status which could be a government (public) or private property. The sampling technique was purposive sampling with 330 respondents who came from Class A Hospitals (90 respondents), Class B Hospitals (140 respondents), Class C Hospitals (80 respondents), and Class D Hospitals (20 respondents). Respondents are patients with diabetes mellitus with the following criteria, i) patients who live in Jabotabek, patients have suffered for 2 years, ii) adult patients over the age of 25 years because the prevalence of diabetes has touched a young age, iii) patients routinely check health at least 2 times a year, and iv) are willing to be interviewed and become respondents. 
The data were collected with surveys through face to face interviews. Patient empowerment is defined as individual who can understand health information and use it effectively, and to gain control and participation in the disease management process in an equal partnership with health care professionals (Ünver \& Atzori, 2013). There are 3 dimensions of patient empowerment that were measured such as patient knowledge, patient control, and patient participation. Patient knowledge is defined as the extent to which patients understand health information, he/she can understand the disease and its implications (Ünver \& Atzori, 2013). Patient control is defined as the adjustment of the patient's psychoanalysis of the disease, perception of competence, control of symptoms, and control of the chosen treatment. Patients are able to monitor the progress of treatment, patient compliance with treatment plans and lifestyle adjustments related to disease (Ouschan et al., 2006; Ünver \& Atzori, 2013). Patient participation is defined as the behavior of patients during medical consultations to influence medical decision making. The extent to which patients are prepared for consultation with health professionals (information) and patients actively participate in consultations with health professionals (Ouschan et al., 2006; Ünver \& Atzori, 2013).

The variable will be measured using the Likert scale with a scale of 1 to 5 , in which 1 indicates the level of strongly disagree and 5 indicates the level of strongly agree. The collected data were analyzed with factor analysis using SPSS software. The procedures for data analysis have been conducted with the following steps. Firstly, the preparing the data matrix $m \times n$, where $m$ is the number of indicators for each dimension of the Patient Empowerment Index (IKP) with as many as 19 questions, while $\mathrm{n}$ is the number of respondents under observation (330 respondents). Indicators are all arranged and directed positively towards performance and the data are ordinal. Secondly, calculating the weights for each type of question with Factor Analysis. Thirdly, calculating the composite index of each dimension of empowerment from the indicators in each dimension. The researchers did this by adding up all the answered indicators after multiplying them first with the weights obtained in the second step. Fourthly, calculating the weights for each dimension produced by Factor Analysis. Lastly, calculating the aggregate composite index of each dimension, by summing each dimension index from the result in step $c$ after multiplying the weight dimension generated in the forth step.

The formulations used in this research for the data analysis were as below:

$$
I D K_{D_{W}}=\frac{\sum_{w=1}^{n}\left(\theta_{Q_{s}} \cdot Q_{i}\right)}{\sum \theta_{Q_{s}}}
$$

Empowerment Dimension Index (IDK) of weight dimension $\left(D_{w}\right.$; where $\mathbf{w}=k_{1}, k_{2}, \ldots, k_{7}$ for the $1^{\text {st }}$ dimension; $\mathrm{W}=L_{1}, \ldots, L_{6}$ for the $2^{\text {nd }}$ dimension, $\mathrm{w}=M_{1}, \ldots, M_{6}$ for the $3^{\text {rd }}$ dimension, and so on) for every patient. The index for each dimension is the sum of the multiplication between the value of the question and the weight of each question $\theta_{Q_{s}}$ divided by the total weight where the number of indicator weights for each dimension $=100$ percent. Calculation of Empowerment Index $\left(I \mathrm{KP}_{\mathrm{j}}\right)$ of patient $j$ is the sum of multiplications between the value of results per dimension $\left(I D K_{D_{W}}\right)$ and dimension weight $\omega_{d w w}$.

$$
I K P_{j}=\frac{\sum_{w=1}^{n}\left(\omega_{D_{w}} \cdot I D K_{i}\right)}{\sum \omega_{D_{w}}}
$$

After obtaining the IKP composite score then it was transformed into a scale of $0-100$ with the following formula:

$$
Y=\frac{(X-\text { Minimum Value } X)}{(\text { Maximum Value } X \text {-Minimum Value } X)} \times 100
$$

\section{RESULTS}

\section{Characteristics of Respondents}

The respondents were diabetic patients consisting of men and women who were mostly married and from Javanese and Sundanese ethnicity. The average age of the respondents was 54.8 years where the highest percentage of respondents was at the interval of age 46-55 years (Table 1). Age and education certainly formed one's perspective and life experience. The education distribution of respondents represented all groups, most of them have a high school education. Consumers who have better education will be responsive to information so they have the potential to influence other respondents on how to behave. The majority of respondents are working as housewives and retirees. In addition, the majority of respondents are registered with BPJS (The Indonesian National Health Insurance System). 
Table 1 Respondent characteristics

\begin{tabular}{lc}
\hline Respondent Characteristics & $(\%)$ \\
\hline Gender & \\
Male & 49.39 \\
Female & 50.61 \\
\hline Marriage Status & \\
Single & 2.42 \\
Married & 80.30 \\
Divorced & 17.28 \\
\hline Age Group & \\
$\leq 25$ years & 0.30 \\
26 - 35 years & 3.33 \\
36 - 45 years & 13.03 \\
46 - 55 years & 37.88 \\
56 - 65 years & 30.00 \\
$>65$ years & 15.45 \\
\hline Education & \\
Elementary School & 14.24 \\
Middle School & 13.33 \\
Senior High School & 41.52 \\
Diploma (D1/D2/D3) & 14.85 \\
Higher Education (S1/S2/S3) & 16.06 \\
\hline Occupation & \\
Private Employees & 19.39 \\
Government Employees & 3.03 \\
Entrepreneur/Professional & 23.63 \\
Others (pension, housewife) & 53.94 \\
\hline Etnicity & \\
Javanese & 38.18 \\
Sundanese & 31.82 \\
Sumateranese & 12.42 \\
Chinese & 1.52 \\
Others & 16.06 \\
\hline BPJS Participation & \\
Yes & \\
No & \\
\hline PatientEmine & \\
\hline & \\
\hline
\end{tabular}

Patient Empowerment Index (IKP)

Patient Empowerment Index (IKP) was composed of 3 dimensions of empowerment, namely patient knowledge, patient control, and patient participation. The patient's knowledge consists of 7 valid indicators (Table 2). The instruments represent the patient's knowledge of the disease that she/he suffered such as information about the treatment of the disease, health information, signs of the disease, as well as the effects of the disease.

Table 2 Shows loading factor of each dimension and indicator of patient empowerment

\begin{tabular}{|c|c|c|c|}
\hline Dimension & Indicator & $\begin{array}{l}\text { Loading } \\
\text { Factor }\end{array}$ & $\begin{array}{l}\text { Loading } \\
\text { Factor }\end{array}$ \\
\hline \multirow[t]{7}{*}{$\begin{array}{l}\text { Patient } \\
\text { Knowledge }\end{array}$} & $\begin{array}{l}\text { Understand } \\
\text { information about } \\
\text { the treatment of } \\
\text { diabetes }\end{array}$ & $0.614^{*}$ & $0.725^{\star}$ \\
\hline & $\begin{array}{l}\text { Understand health } \\
\text { information in } \\
\text { written form }\end{array}$ & $0.677^{*}$ & \\
\hline & $\begin{array}{l}\text { Understand health } \\
\text { information in the } \\
\text { form of web / media }\end{array}$ & $0.668^{*}$ & \\
\hline & $\begin{array}{l}\text { Understand the } \\
\text { impact of disease }\end{array}$ & $0.657^{*}$ & \\
\hline & $\begin{array}{l}\text { Knowing the signs/ } \\
\text { symptoms of the } \\
\text { disease }\end{array}$ & $0.670^{*}$ & \\
\hline & $\begin{array}{l}\text { Knowing the } \\
\text { progress of the } \\
\text { disease }\end{array}$ & $0.773^{*}$ & \\
\hline & Feel well informed & $0.731^{*}$ & \\
\hline \multirow[t]{6}{*}{$\begin{array}{l}\text { Patient } \\
\text { Control }\end{array}$} & $\begin{array}{l}\text { Regularly check } \\
\text { health status }\end{array}$ & $0.492^{*}$ & $0.808^{*}$ \\
\hline & $\begin{array}{l}\text { Inform when signs } \\
\text { of disease appear }\end{array}$ & $0.553^{*}$ & \\
\hline & $\begin{array}{l}\text { Perform regular } \\
\text { health checks }\end{array}$ & $0.759^{*}$ & \\
\hline & $\begin{array}{l}\text { Regulate diet and } \\
\text { lifestyle }\end{array}$ & $0.608^{*}$ & \\
\hline & $\begin{array}{l}\text { Following the } \\
\text { prescribed } \\
\text { treatment }\end{array}$ & $0.615^{*}$ & \\
\hline & $\begin{array}{l}\text { Do the } \\
\text { documentation of } \\
\text { health checks }\end{array}$ & $0.795^{*}$ & \\
\hline \multirow[t]{6}{*}{$\begin{array}{l}\text { Patient } \\
\text { Participation }\end{array}$} & $\begin{array}{l}\text { Regularly request } \\
\text { medical test/ report } \\
\text { results }\end{array}$ & $0.593^{*}$ & $0.883^{*}$ \\
\hline & $\begin{array}{l}\text { Think first about the } \\
\text { questions that will } \\
\text { be asked }\end{array}$ & $0.613^{*}$ & \\
\hline & $\begin{array}{l}\text { Look for additional } \\
\text { information / } \\
\text { opinions from other } \\
\text { sources }\end{array}$ & $0.746^{*}$ & \\
\hline & $\begin{array}{l}\text { Have the courage } \\
\text { to express opinions }\end{array}$ & $0.764^{*}$ & \\
\hline & $\begin{array}{l}\text { Get attention and } \\
\text { consider her/his } \\
\text { opinion by doctors / } \\
\text { nurses }\end{array}$ & $0.692^{*}$ & \\
\hline & $\begin{array}{l}\text { Have a treatment } \\
\text { plan based on } \\
\text { doctor's opinion } \\
\text { and personal views }\end{array}$ & $0.692^{*}$ & \\
\hline
\end{tabular}


Patient control consists of 6 valid indicators. Patient control is expected to allow patients to understand the extent to which patients monitor their own treatment/ progress and the extent of patient compliance with treatment plans and disease-related lifestyle adjustments (Ouschan et al., 2006; Ünver \& Atzori, 2013). Patient participation is measured by 6 valid indicators. This dimension measures patient participation in the process of healing/ treating the disease.

Each dimension has indicators that measure that dimension. The empowerment dimension has each indicator which has the value of Measure of Sampling Adequacy (MSA) $>0.5$ in all analyses. In addition, the values of the Kaiser Meyer Olkin (KMO) and sig were also produced. Bartlett's Test of Sphericity $<0.000$ which shows that it is feasible to do factor analysis. The measurement of the composite index value calculated the weight of indicators and dimensions using Factor Analysis is shown in Table 3 . The patient participation dimension has the highest weight, then followed by the control dimension by 33.40 percent and finally the knowledge dimension.

Overall Patient Empowerment Index score obtained from 330 respondents of diabetic patients was 68.84 where the index values of each IKP constituent dimension were as follows; knowledge dimension is 71.74 , control dimension is 70.75 , and participation dimension is 65.44. The Patient Empowerment Index score was generated from the composite score of all indicators and their constituent dimensions. Patient Empowerment Index scores were at intervals between 0-100. Patient Empowerment Index was grouped into five categories based on Patient Empowerment Index scores as shown in Table 4. The score used in this research is adopted from the study of Simanjuntak and Yuliati (2016) regarding the Consumer Empowerment Index (IKK).

Table 3 Assessment of dimensions and weight of index scores

\begin{tabular}{lccc}
\hline Dimension & $\begin{array}{c}\text { Dimension } \\
\text { Weight }\end{array}$ & $\begin{array}{c}\text { Indicato } \\
\mathrm{r}\end{array}$ & $\begin{array}{c}\text { Scor } \\
\mathrm{e}\end{array}$ \\
\hline Knowledge & 25.84 & 7 & 71.74 \\
Control & 33.40 & 6 & 70.75 \\
$\begin{array}{l}\text { Participatio } \\
\mathrm{n}\end{array}$ & 40.76 & 6 & 65.44 \\
\hline Total Score & 100 & 19 & 68.84 \\
\hline
\end{tabular}

Table 4 Operational definition of the IKP

\begin{tabular}{|c|c|c|}
\hline Category & $\begin{array}{l}\text { IKP } \\
\text { Score }\end{array}$ & Operational Definition \\
\hline Helpless & $0 \leq 20$ & $\begin{array}{l}\text { Do not have sufficient } \\
\text { knowledge about diabetes } \\
\text { and its management }\end{array}$ \\
\hline Understand & $21 \leq 40$ & $\begin{array}{l}\text { Have knowledge about } \\
\text { diabetes and its } \\
\text { management }\end{array}$ \\
\hline Able & $41 \leq 60$ & $\begin{array}{l}\text { Able to understand the } \\
\text { condition of their disease } \\
\text { and make choices in its } \\
\text { management }\end{array}$ \\
\hline Critical & $61 \leq 80$ & $\begin{array}{l}\text { Have control over the } \\
\text { management of their } \\
\text { disease conditions in daily } \\
\text { life }\end{array}$ \\
\hline Empowered & $\begin{array}{c}80 \leq \\
100\end{array}$ & $\begin{array}{l}\text { Have knowledge, control, } \\
\text { and active participation } \\
\text { with health professionals } \\
\text { in managing diabetes and } \\
\text { its management. }\end{array}$ \\
\hline
\end{tabular}

Based on the data, the majority of respondents in this study had an empowerment score (IKP) which was in the critical category (81.52 percent) while the able ones were 16.36 percent, and those who were empowered were only 1.82 percent (Table 5). The number of patients included in the critical category can be caused by demographic, information technology support and health facilities and health workers factors in the Jabodetabek area which are relatively good compared to other regions. Judging from the demographics, this research found that the majority of patients in this study had high school education (41.52 percent) and higher education (30.91 percent).

Table 5 Distribution of patient empowerment

\begin{tabular}{|c|c|c|c|}
\hline Category & $\begin{array}{l}\text { IKP } \\
\text { Score }\end{array}$ & $\begin{array}{c}\text { No. Of } \\
\text { Patients }\end{array}$ & Percentage (\%) \\
\hline Helpless & $\begin{array}{c}0 \leq \\
\mathrm{IKMM} \leq \\
20\end{array}$ & 0 & 0.00 \\
\hline Understand & $\begin{array}{c}21 \leq \\
\text { IKMM } \\
40\end{array}$ & 1 & 0.30 \\
\hline Able & $\begin{array}{c}41 \leq \\
\text { IKMM } \\
60\end{array}$ & 54 & 16.36 \\
\hline Critical & $\begin{array}{c}61 \leq \\
\text { IKMM } \\
80\end{array}$ & 269 & 81.52 \\
\hline Empowered & $\begin{array}{c}81 \leq \\
\text { IKMM } \\
100\end{array}$ & 6 & 1.82 \\
\hline Total & & 330 & 100.00 \\
\hline
\end{tabular}


Another finding discovered that a fairly good education supported by good information technology in the Jabodetabek area are the driving factors for most medical consumers in this research to fall into the category of critical category.

\section{DISCUSSION}

Characteristics of respondents vary in terms of age group, status, gender, occupation, ethnicity, insurance and education. Respondents have represented each hospital proportionally and the number of representatives. Respondent characteristics describe having represented the existing population. The number of respondents' characteristics for gender is balanced, according to Morewitz (2006) study showed that gender is not consistently associated with an increase in diabetes risk factors. While of the types of work a half of respondents were retired and housewives. Sari (2017) found that the type work has a significant effect on the cost due to suffering from type 2 diabetes melitus.

All questions used in the survey are valid and reliable based on loading factor result. In the dimension of patient knowledge, the question that has the highest weight is knowing the symptoms of the disease, the control dimension of the patient who has the highest weight is documenting the results of health checks and on the dimension of patient participation is having the courage to express opinions and questions. Each indicator has explained the dimensions well and adequately. Each of these dimensions has described the construct precisely. Existing constructs, then the index of patient empowerment is calculated by factor analysis.

The usefulness of the index is to measure consumer awareness and understanding of rights and obligations and their ability to interact with markets. The Consumer Empowerment Index uses its dimensions prepurchase, purchase and post-purchase. The study of Nardo, Loi, Rosati, and Manca (2011) measured the index of consumer empowerment in European consumers using three dimensions, namely: (i) consumer skills as basic numerical and financial skills and their knowledge of logos and symbols; (ii) level of consumer information as consumer knowledge of their rights (awareness of the injustice of contractual requirements, unfair advertising practices, guarantee rights. long-distance purchase rights, prices, government and non- government institutions that protect consumers, different sources of information about consumer affairs; and (iii) consumer assertiveness as complaints and reporting behavior, and consumer experience of offers that are misleading or fraudulent. In this research, Patient Empowerment Index (IKP) was built from 3 dimensions of empowerment, they were patient knowledge, patient control, and patient participation. The three criteria are also in line with the previous research concepts of Hechanova, Alampay, and Franco (2006); Aujoulat et al. (2007); Ibrahim and Alkire (2007); Meyerson and Kline (2008); Herbert, Gagnon, Rennick, and O'Loughlin (2009); Drury and Reicher (2009); Anderson and Funnell (2010); Pulvirenti, Mcmillan, and Lawn (2014); Mcguckin, Storr, Longtin, Allegranzi, and Pittet (2011); Barr et al. (2015) Rosyada and Trihandini (2013) and various other studies.

The patient empowerment index results obtained were 68.84, following is an explanation of the value of the three dimensions of patient empowerment. According to Ünver dan Atzori (2013), patient knowledge is the extent to which patients understand health information, can understand disease and its implications. The results showed that the patient knowledge index was the highest 71.74 compared to other dimensions, this means that in the category of patients who were critical in terms of knowing health information and being able to understand the disease and its implications. Patient control is the patient's ability to control the symptoms of the disease and the selected treatment. In addition patients are able to monitor / progress treatment (Ouschan et al., 2006; Ünver \& Atzori, 2013). The results showed that the patient control index was 70.75 , this means that in the category of patients who were critical in terms of ability to make psychoanalytic adjustments to the disease, perception of competence, control of symptoms and able to monitor the progress of treatment. Patient behaviour during medical consultations to influence medical decision making is named by patient participations (Ouschan et al., 2006; Ünver \& Atzori, 2013). The results showed that the patient control index was the lowest 65.44 compared to other dimensions, this means that in the category of patients who were critical in terms of actively participating in consultations with health professionals

The patient empowerment index is higher than the index of consumer empowerment (IKK). 
The Consumer Empowerment Index (IKK) in Indonesia in 2015 was still relatively low at 38.47 on a scale of $0-100$ (Simanjuntak \& Yuliati, 2016). The results of a survey conducted by Simanjuntak and Yuliati (2016) pointed out that the average index of consumer empowerment in 21 provinces was relatively low, which was 31.05 with an average IKK in urban areas (33.46) higher than in rural areas (28.15). The highest Consumer Empowerment Index value based on the province of DKI Jakarta with achievement of 38.36 whereas, the lowest value of the Consumer Empowerment Index was Papua with achievement of 24.61. Refereing expert interview the higher IKP value than IKK is possible because it has been a chronic disease for years so that knowledge, participation and control have begun to increase.

In addition, the effects of chronic diseases are directly felt by patients/ respondents so they are more active in the empowerment of patients. Education tends to influence the habits of respondents (patients) in accessing health information from the internet or other similar media which ultimately affects patient knowledge (Sari, 2018). Patient control can be used as a measure of patient compliance and discipline in carrying out treatment. Patient education is an effective way to improve patient control. The patients who are given an understanding about the benefits of the actions they take, will encourage them to be more discipline. Patient participation measures the extent to which patients are prepared for consultation with health professionals (information) and the extent to which patients are actively participated in consultations with health care professionals. (Hechanova et al., 2006)

This research found that there is no helpless patient in this research. Helpless individuals are described as having high self-esteem and self-efficacy, feelings of control over their lives, high critical awareness, and high community participation (Zimmerman, 2000). The empowerment index is built on a multidimensional process that helps people/ patients to gain control of their own lives and increases the capacity of people/ patients to act on important issues (Halcomb \& Davidson, 2006; Valentijn, Schepman, Opheij, \& Bruijnzeels, 2013.; World Health Organization, 2012). At the individual level, clinical integration highlights a people-focused perspective, ensuring that the users experience ongoing care. Empowerment level is contributed by patient knowledge, patient control and patient participation.

Reffering the result of this result government should; i) design empowerment indices for each province in Indonesia that are used as the benchmark of the empowerment so that the cost of the BPJS may be decreased (prenventively); ii) empowerment index is also used to improve patient compliance with BPJS premiums; iii) patient empowerment index can be used as a Key Performance Indicator (KPI) for the directorate of non-communicable diseases of the Ministry of Health; iv) the government needs to increase knowledge and participation of patients through educational programs in hospitals that have large claims for BPJS; v) conduct national campaigns programs to raise awareness on chronic diseases; vi) improve research on preventive therapy of chronic diseases; and vii) open a 24-hour online consultation program to encourage patient empowerment. Meanwhile patients should i) play an active role in each consultation meeting with health / medical personnel by actively asking about the goals and benefits of the treatment provided; ii) patients and families of patients should actively seek information to improve health literacy; iii) patients or family members should become community members by involving in some sharing communities; and iv) to strengthen relational relationships with families and communities in increasing patient empowerment. Implications for the provision of health services needs to i) create an environment that supports participation, which is more communicative, some trainings to improve the communication skills of health care providers to increase patient participation should be conducted; ii) create remote monitoring online, on-line consultations and information platforms (e-health) that can be accessed easily and affordable for everyone.

\section{CONCLUSIONS AND SUGESTIONS}

In the patient empowerment index study, the total score was 68.84 in the critical category. The empowerment index consists of three dimensions which are knowledge dimensions weighing 25.84 percent, control dimensions weighing 33.44 percent and participation dimensions weighing 40.76 percent. The Patient Empowerment Index (IKP) which is higher in value than the Consumer Empowerment Index (IKK) is possible because it has been a chronic disease for years so that knowledge, participation and control have begun to increase. 
This study has limitations in the study area that conducted only in certain hospitals in Jakarta, Bogor, Tangerang and Bekasi. Thus, the researchers give several suggestions for further researches; i) future studies need to examine the central and eastern regions of Indonesia; ii) the study should distinguish the types of hospitals referred to by patients with diabetes mellitus. Besides that, a patient empowerment index study is also needed to study in the case of other chronic diseases such as heart disease and hypertension.

\section{REFERENCES}

Almunawar, M. N., Anshari, M., \& Younis, M. Z. (2015). Incorporating customer empowerment in mobile health. Health Policy and Technology. 4(4), 312-319. https://doi.org/10.1016/j.hlpt.2015.08.008.

Alshibly, H., \& Chiong, R. (2015). Customer empowerment: Does it influence electronic government success? A citizencentric perspective. Electronic Commerce Research and Applications. 14(6), 393404.

https://doi.org/10.1016/j.elerap.2015.05.0 03.

Anderson, R. E., \& Huang, W. Y. (2006). Empowering salespeople: personal, managerial, and organizational perspectives. Psychology and Marketing. 23(2), 139-159. https://doi.org/10.1002/mar.20104.

Anderson, R. M., \& Funnell, M. M. (2010). Patient empowerment: myths and misconceptions. Patient Education and Counseling, 79(3), 277-282. https://doi.org/10.1016/j.pec.2009.07.025.

Aujoulat, I., d'Hoore, W., \& Deccache, A. (2007, April). Patient empowerment in theory and practice: Polysemy or cacophony? Patient Education and Counseling, 66(1), 13-20. https://doi.org/10.1016/j.pec.2006.09.008.

Aujoulat, I., Marcolongo, R., Bonadiman, L., \& Deccache, A. (2008). Reconsidering patient empowerment in chronic illness: a critique of models of self-efficacy and bodily control. Social Science and Medicine, 66(5), 1228-1239. https://doi.org/10.1016/j.socscimed.2007. 11.034

Barr, P. J., Scholl, I., Bravo, P., Faber, M. J., Elwyn, G., \& McAllister, M. (2015). Assessment of patient empowerment - a systematic review of measures. PLOS
ONE. 10(5), $\quad 1-24$ https://doi.org/10.1371/journal.pone.0126 553.

Boyd, D. E., McGarry, B. M., \& Clarke, T. B. (2016). Exploring the empowering and paradoxical relationship between social media and CSR activism. Journal of Business Research. 69(8), 2739-2746. https://doi.org/10.1016/j.jbusres.2015.11.0 09.

Broniarczyk, S. M., \& Griffin, J. G. (2014). Decision difficulty in the age of consumer empowerment. Journal of Consumer Psychology. 23(4), 608-625. https://doi.org/10.1016/j.jcps.2014.05.003.

Camacho, N., De Jong, M., \& Stremersch, S. (2014). The effect of customer empowerment on adherence to expert advice. International Journal of Research in Marketing. 31(3), 293-308 https://doi.org/10.1016/j.jiresmar.2014.03. 004.

Cannoy, S. D. (2009). Consumer empowerment in healthcare information exchange: an investigation using the grounded theory approach. (Dissertation) University of North Carolina. North Carolina, United State of America.

Chou, C., Yang, K. P., \& Jhan, J. (2015). Empowerment strategies for ideation through online communities. Creativity and Innovation Management. 24(1), 169181. https://doi.org/10.1111/caim.12104.

Drury, J., \& Reicher, S. (2009). Collective psychological empowerment as a model of social change: Researching crowds and power. Journal of Social Issues, 65(4), 707-725. https://doi.org/10.1111/j.15404560.2009.01622.x.

Ellinger, A. E., Keller, S. B., \& Baş, A. B. E. (2010). The empowerment of frontline service staff in $3 \mathrm{pl}$ companies. Journal of Business Logistics, 31(1), 79-98. https://doi.org/10.1002/j.21581592.2010.tb00129.x.

Fernandez, S., \& Moldogaziev, T. (2013). Employee empowerment, employee attitudes, and performance: testing a causal model. Public Administration Review. 73(3), 490-506. https://doi.org/10.1111/puar.12049.

Fong, K. H., \& Snape, E. (2015). Empowering leadership, psychological empowerment and employee outcomes: testing a multilevel mediating model. British Journal of 
Management. 26(1), 126-138. https://doi.org/10.1111/1467-8551.12048.

Fuchs, C., \& Schreier, M. (2011). Customer empowerment in new product development. Journal of Product Innovation Management. 28(1), 17-32. https://doi.org/10.1111/j.15405885.2010.00778.x.

Gallan, A. S., Jarvis, C. B., Brown, S. W., \& Bitner, M. J. (2013). Customer positivity and participation in services: an empirical test in a health care context. Journal of the Academy of Marketing Science. 41(3), 338-356. https://doi.org/10.1007/s11747012-0307-4.

Halcomb, E. J., \& Davidson, P. M. (2006). The role of practice nurses in an integrated model of cardiovascular disease management in Australian general practice. Australian Journal of Primary Health, 12(2), 34-44. https://doi.org/10.1071/PY06020.

Hau-siu Chow, I., Wing-chun Lo, T., Sha, Z., \& Hong, J. (2006). The impact of developmental experience, empowerment, and organizational support on catering service staff performance. International Journal of Hospitality Management. 25(3), 478-495. https://doi.org/10.1016/j.ijhm.2005.03.002.

Hechanova, M. R. M., Alampay, R. B. A., \& Franco, E. P. (2006). Psychological empowerment, job satisfaction and performance among Filipino service workers. Asian Journal of Social $\begin{array}{lll}\text { Psychology. } & \text { 9(1), }\end{array}$ https://doi.org/10.1111/j.1467839X.2006.00177.x.

Herbert, R. J., Gagnon, A. J., Rennick, J. E., \& O'Loughlin, J. L. (2009). A systematic review of questionnaires measuring health-related empowerment. Research and Theory for Nursing Practice. 23(2), 107-132. https://doi.org/10.1891/15416577.23.2.107.

Ibrahim, S., \& Alkire, S. (2007). Agency and empowerment: A proposal for internationally comparable indicators. Oxford Development Studies. 35(4), 379403.

https://doi.org/10.1080/136008107017018 97.

IDF. (2017). IDF diabetes atlas eighth edition 2017. International Diabetes Federation.

KEMENKES. (2015). Rencana strategis kementerian kesehatan. In Jakarta.

\section{Kementerian Kesehatan.}

Khong, K. W., Onyemeh, N. C., \& Chong, A. Y. L. (2013). BSEM estimation of network effect and customer orientation empowerment on trust insocial media and network environment. Expert Systems with Applications. 40(12), 4858-4870. https://doi.org/10.1016/j.eswa.2013.02.02 0 .

Mcguckin, M., Storr, J., Longtin, Y., Allegranzi, B., \& Pittet, D. (2011). Patient empowerment and multimodal hand hygiene promotion: a win-win strategy. American Journal of Medical Quality. 26(1), 10-17. https://doi.org/10.1177/106286061037313 8.

Meyerson, S. L., \& Kline, T. J. B. (2008). Psychological and environmental empowerment: Antecedents and consequences. Leadership and Organization Development Journal, 29(5), 444-460.

https://doi.org/10.1108/014377308108870 49.

Midha, V. (2012). Impact of consumer empowerment on online trust: an examination across genders. Decision Support Systems. 54(1), 198-205. https://doi.org/10.1016/j.dss.2012.05.005.

Morewitz, S. J. (2006). Chronic diseases and health care: new trends in diabetes, arthritis, osteoporosis, fibromyalgia, low back pain, cardiovascular disease, and cancer. In New York. Springer Science \& Business Media.

Nardo, M., Loi, M., Rosati, R., \& Manca, A. R. (2011). The consumer empowerment index. a measure of skills, awareness and engagement of European consumers. JRC Scientific and Technical Reports No. EUR 24791 1-232.

Nursasi, A. Y. (2015). Efektivitas model pemberdayaan perawat, kader, keluarga dan klien (p2k3) terhadap kemandirian klien tuberkulosis paru dalam melakukan perawatan diri di Kota Depok. (Disertasi) Universitas Indonesia. Depok, Indonesia.

Nygårdh, A., Malm, D., Wikby, K., \& Ahlström, G. (2012). The experience of empowerment in the patient-staff encounter: The patient's perspective. Journal of Clinical Nursing, 21(5-6), 897$904 . \quad$ https://doi.org/10.1111/j.13652702.2011.03901.x.

Ouschan, R., Sweeney, J., \& Johnson, L. 
(2006). Customer empowerment and relationship outcomes in healthcare consultations. European Journal of Marketing, 40(9-10), 1068-1086. https://doi.org/10.1108/030905606106810 14.

Prabowo, A., Wirjodirdjo, B., \& Vanany, I. (2012). Analisis kebijakan penggunaan obat generik di indonesia serta dampaknya pada biaya belanja obat masyarakat studi kasus pada obat penyakit diabetes mengguakan pendekatan sistem dinamik. Jurnal Teknik ITS, 1(1), A592-A594.

Pulvirenti, M., Mcmillan, J., \& Lawn, S. (2014). Empowerment, patient centred care and self-management. Health Expectations, 17(3), 303-310. https://doi.org/10.1111/j.13697625.2011.00757.x.

Rosyada, A., \& Trihandini, I. (2013). Determinan komplikasi kronik diabetes melitus pada lanjut usia. Kesmas: National Public Health Journal, 7(9), 395402.

Sari, K. (2018). Perkembangan asuransi kesehatan swasta di Indonesia 20122016. Jurnal Ekonomi Kesehatan Indonesia, 2(2), 48-58.

Sari, L. S. (2017). Analisis biaya akibat sakit serta kualitas hidup pasien diabetes mellitus tipe 2 dengan penyakit jantung. Jurnal Ekonomi Kesehatan Indonesia, 1(3), 126-131.

Shankar, A., Cherrier, H., \& Canniford, R. (2006). Consumer empowerment: a Foucauldian interpretation. European Journal of Marketing, 40(9-10), 10131030.

https://doi.org/10.1108/030905606106809 89.

Simanjuntak, M. (2014). Tingkat keberdayaan dan strategi pemberdayaan konsumen. (Disertasi) Institut Pertanian Bogor. Bogor, Indonesia.

Simanjuntak, M., Amanah, S., Puspitawati, H., and Asngari, P. (2013). Modelling Consumer Empowerment Level. Economic Journal of Emerging Market. 5 / 2. ISSN : 20863128.http://journal.uii.ac.id/index.php/JEP/ article/view/3519.

Simanjuntak, M. (2015). Consumer Empowerment Index among Undergraduate Students of Bogor Agricultural University, Indonesia; Asian
Journal of Business and Management $3 /$ 3 : 183 - 191. ISSN: 2321-2802. http://www.ajouronline.com/index.php/AJB M/article/view/1538/1406.

Simanjuntak, S., Amanah, S., Puspitawati, H., and Asngari, PS. (2014). Consumer Empowerment Profile in Rural and Urban Areas. ASEAN Marketing Journal (AMJ) VI / 1 : 38-49.ISSN: 2085-5044, E-ISSN: 2356-2242.http://journal.ui.ac.id/amj.

Stewart Loane, S., \& D'Alessandro, S. (2014). Empowered and knowledgeable health consumers: The impact of online support groups on the doctor-patient relationship. Australasian Marketing Journal. 22(3), 238-245

https://doi.org/10.1016/j.ausmj.2014.08.00 7.

Sumarwan, U. (2011). Perilaku konsumen: Teori dan penerapannya dalam pemasaran. Bogor: Ghalia Indonesia.

Tol, A., Shojaeezadeh, D., Sharifirad, G., Alhani, F., \& Tehrani, M. M. (2012). Determination of empowerment score in type 2 diabetes patients and its related factors. JPMA-Journal of the Pakistan Medical Association, 62(1), 16-20.

Ünver, Ö., \& Atzori, W. (2013). Questionnaire for patient empowerment measurement version 1.0 (document d3. 2). SUSTAINS: Support USers To Access INformation and Services, 1-74.

Valentijn, P. P., Schepman, S. M., Opheij, W., \& Bruijnzeels, M. A. (2013). Understanding integrated care: a comprehensive conceptual framework based on the integrative functions of primary care. International Journal of Integrated Care, 13, 1-12. https://doi.org/10.5334/ijic.886.

World Health Organization. (2012). World Health Statistics: A Snapshot of Global Health. World Health Organisation: Retrieved from http://apps.who.int/iris/bitstream/10665/70 889/1/WHO_IER_HSI_12.1_eng.pdf?ua= 1.

Zimmerman, M A. (2000). Empowerment Theory: Psychological, Organizational and Community Levels of Analysis. Handbook of Community Psychology. Dordrecht, Netherlands (NL). Kluwer Academic Publishers. https://doi. org/10.1007/978-14615-4193-6_2.

Zimmerman, Marc A. (1990). Taking aim on empowerment research: on the distinction 
between individual and psychological conceptions. American Journal of
Community Psychology, 18(1), 169-177. https://doi.org/10.1007/BF00922695. 